\title{
ANALISA KEPATUHAN PAJAK DENGAN PENDEKATAN TEORI PERILAKU TERENCANA (THEORY OF PLANNED BEHAVIOR) (TERHADAP WAJIB PAJAK ORANG PRIBADI DI PROVINSI DKI JAKARTA)
}

\author{
Hadi Saputra \\ Program Studi Akuntansi Fakultas Ekonomi \\ Universitas Tarumanagara, Jakarta \\ Email: hadysp@ymail.com
}

Masuk : 28-08-2018, revisi: 27-05-2019, diterima untuk diterbitkan :09-08-2019

\begin{abstract}
ABSTRAK
Rendahnya kesadaran wajib pajak orang pribadi dalam membayar pajak telah menjadi masalah utama negara berkembang dalam aspek pajak. Rendahnya kepatuhan wajib pajak orang pribadi dapat dilihat dan dikaji dari sisi psikologi wajib pajak (sikap, norma subjektif, kontrol perilaku yang dipersepsikan, niat, dan perilaku kepatuhan pajak). Penelitian ini merupakan penelitian eksplanatori, pengambilan sample dalam penelitian ini menggunakan teknik non-probability sampling dengan kriteria wajib pajak orang pribadi yang terdaftar dan memiliki Nomor Pokok Wajib Pajak (NPWP) dan melaporkan Surat Pemberitahuan Pajak (SPT) di Kantor Pelayanan Pajak (KPP) di Provinsi DKI Jakarta. Adapun instrument penelitian dilakukan pretest pada tanggal 28-29 Mei 2018 (2 Hari). Hasil kuesioner yang sudah valid dan reliabel kemudian dilakukan penyebaran ulang untuk keperluan analisa statistik dalam penelitian ini, kuesioner disebarkan pada tanggal 28 Mei - 05 Juli 2018 (39 Hari). Jumlah sampel yang diolah sebanyak 170 tanggapan wajib pajak, dan data diolah dengan metode Structural Equation Modeling (SEM) berbasis Partial Least Square (PLS) dengan bantuan program SmartPLS 3.0. Hasil pengujian hipotesis menunjukkan bahwa sikap dan kontrol perilaku yang dipersepsikan berpengaruh positif dan signifikan terhadap niat berperilaku patuh terhadap pajak, sedangkan norma subjektif berpengaruh positif namun tidak signifikan terhadap niat berperilaku patuh terhadap pajak. Hasil penelitian mengungkapkan kesesuaian dengan Teori Perilaku Terencana (Theory of Planned Behavior) bahwa secara teoritis perilaku wajib pajak disebabkan oleh adanya niat untuk berprilaku patuh terhadap pajak yang direfleksikan oleh sikap, norma subjektif dan kontrol perilaku yang dipersepsikan oleh wajib pajak orang pribadi di Provinsi DKI Jakarta.
\end{abstract}

Kata Kunci: Sikap, norma subjektif, kontrol perilaku yang dipersepsikan, niat, perilaku kepatuhan pajak

\begin{abstract}
The low awareness of individual taxpayers in paying taxes has become a major problem for developing countries in the tax aspect. The low compliance of individual taxpayers can be seen and assessed in terms of the taxpayer's psychology (attitudes, subjective norms, perceived behavioral controls, intentions, and tax compliance behavior). This research is an explanatory research, taking samples in this study using non-probability sampling techniques with criteria for individual taxpayers who are registered and have a Taxpayer Identification Number (NPWP) and report the Tax Return (SPT) in the Tax Service Office (KPP) in DKI Jakarta Province. The research instrument was pretested on 28-29 May 2018 (2 Days). The results of a valid and reliable questionnaire were then re-distributed for the purposes of statistical analysis in this study, the questionnaire was distributed on 28 May - 05 July 2018 (39 Days). The number of samples processed was 170 taxpayer responses to the questionnaire distributed, and the data was processed using Structural Equation Modeling (SEM) method based on Partial Least Square (PLS) with the help of the SmartPLS 3.0 program. The results of hypothesis testing show that attitude and perceived behavior control have a positive and significant effect on the intention to behave in compliance with taxes, while subjective norms have a positive but not significant effect on the intention to behave in compliance with taxes. The results of the study reveal conformity with the Theory of Planned Behavior that theoretically taxpayer behavior is caused by the intention to behave obediently to taxes which is reflected by attitudes, subjective norms and behavioral controls perceived by individual taxpayers in DKI Jakarta Province.
\end{abstract}

Keywords: attitude, subjective norms, perceived behavioral control, intentions, tax compliance behavior 


\section{PENDAHULUAN}

\section{Latar Belakang}

Rendahnya kesadaran wajib pajak orang pribadi yang menjadi masalah negara berkembang, hal ini juga dilatar belakangi oleh sistem perpajakan yang dimulai pada tahun 1984 sistem pemungutan pajak di Indonesia menggunakan sistem self assessment yang berbeda dengan sistem pemungutan pajak yang dipakai sebelumnya. Dimana sistem ini akan efektif jika kepatuhan sukarela sudah terbentuk (voluntary compliance).

Faktanya, menunjukkan bahwa tingkat kepatuhan wajib pajak di Indonesia masih sangat rendah, terlihat dari tax gap tahun 2017 sebesar 10,26\% yang menunjukkan shortfall sebesar Rp. 132,4 triliun dan tax ratio yang terus mengalami penurunan selama 5 tahun terakhir. Berdasarkan Direktoriat Jendral Pajak tax rasio pada tahun 2012 sebesar 11,4\%, 2013 sebesar 11,3\%, 2014 sebesar 10,9\%, 2015 sebesar 10,8\%, 2016 sebesar 10,4\%, dan 2017 sebesar 10,1\% dibandingkan dengan Produk Domestik Bruto (PDB) (BPS, 2018) dan tax ratio Indonesia berada dibawah negara berkembang lain di Asia. Jika dibandingkan dengan negara berkembang lain, rasio pajak Indonesia berada dibawah negara berkambang lain dikawasan Asia seperti Malaysia 15,5\%, Thailand 17\%, Filipina 14,4\%, Vietnam 13,8\%.

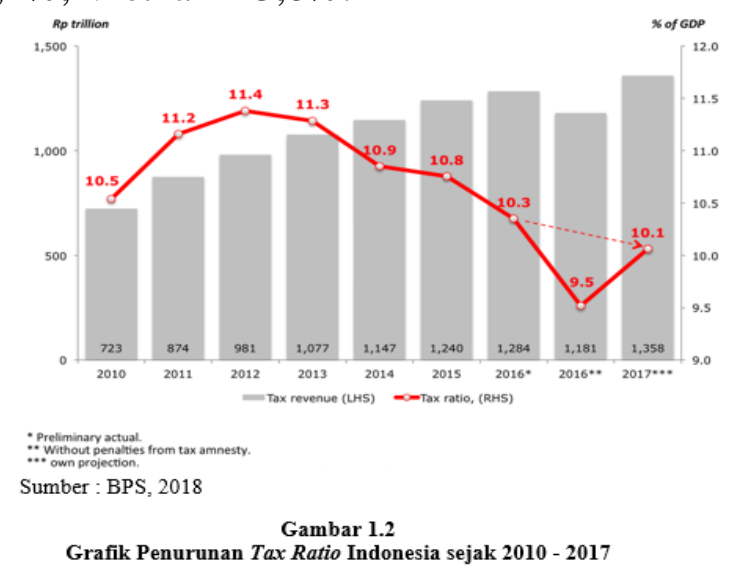

Dengan tingkat rasio pajak yang rendah, menunjukan bahwa pendapatan yang dikumpulkan oleh pemerintah Indonesia juga rendah, untuk itu perlu dikaji dan diteliti secara intensif faktor yang mempengaruhi kepatuhan wajib pajak dan motivasi wajib pajak untuk berperilaku patuh. Fenomena kepatuhan wajib pajak di Indonesia yang rendah ini menjadi motivasi pertama peneliti untuk meneliti secara intensif mengenai faktor yang mempengaruhi kepatuhan wajib pajak di Indonesia khususnya di DKI Jakarta, dikarenakan DKI Jakarta merupakan daerah dengan tingkat kepatuhan yang paling tinggi di Indonesia dibandingkan dengan daerah lain yang di Indonesia.

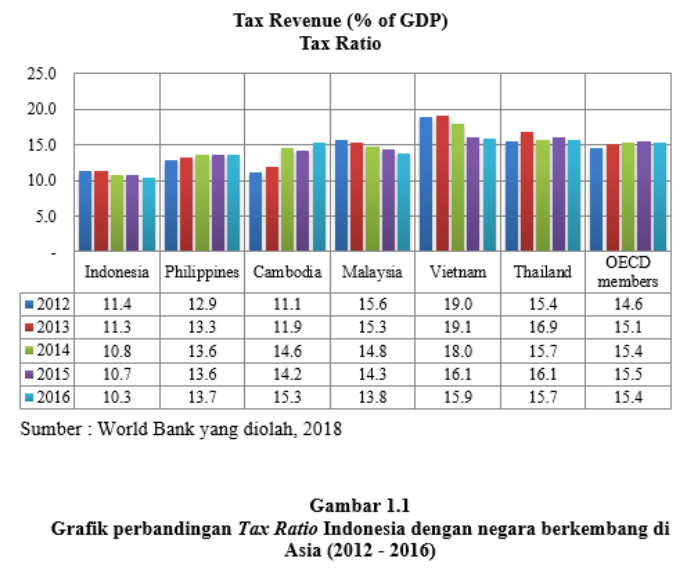


Kepatuhan wajib pajak orang pribadi dapat dilihat dari sisi psikologis individu wajib pajak. Ada beberapa teori perilaku yang bisa digunakan untuk meramalkan perilaku individu. (Widi dan Bambang, 2012) menyatakan bahwa Teori Perilaku Terencana (Theory of Planned Behavior) yang dikembangkan (Ajzen, 1991) merupakan salah satu teori sikap yang banyak diaplikasikan dalam beragam perilaku. (Arniati, 2009) juga menyatakan bahwa Teori Perilaku Terencana salah satu model psikologi sosial yang paling sering digunakan untuk meramalkan perilaku dan merupakan prediksi perilaku yang baik karena diseimbangkan oleh niat untuk melaksanakan perilaku. Atas dasar inilah yang menjadikan motivasi kedua peneliti memilih untuk menggunakan Teori Perilaku Terencana dalam menjelaskan fenomena atau faktor yang memengaruhi kepatuhan wajib pajak di DKI Jakarta. Dalam Teori Perilaku Terencana, perilaku yang ditampilkan oleh wajib pajak timbul karena adanya niat untuk berperilaku. Munculnya niat berperilaku ditentukan oleh tiga faktor penentu, yaitu: sikap terhadap perilaku; norma subjektif; dan kontrol perilaku yang dipersepsikan (Ajzen, 1991).

Penelitian kepatuhan wajib pajak dengan pendekatan Teori Perilaku Terencana telah banyak dilakukan baik di Indonesia maupun diluar negeri seperti (Trivedi, 2005) di Toronto Kanada, (Benk, et al., 2011) dalam penelitiannya di Turki dan juga (Martha, 2013) dalam penelitiannya di Selandia Baru, (Mutikasari, 2007) di Surabaya, (Widi dan Agro, 2010) dalam penelitiannya di Surabaya, (Pangestu dan Rusmana, 2012) dalam penelitiannya di Purwokerto, (Widi dan Bambang, 2012) dalam penelitiannya di Pluit - Jakarta, (Handoyono, 2014) dalam penelitiannya di Semarang, (Tarmidi dan Waluyo, 2014) dalam penelitiannya di PMA Jakarta, (Damayanti, 2015) dalam penelitiannya di Provinsi Jawa Tengah, (Wahyuni, et al., 2017) dalam penelitiannya di Bali, (Novianti, 2017) dalam penelitiannya di Surabaya. Yang menyatakan penelitian tentang perilaku kepatuhan wajib pajak bisa dilakukan dengan menggunakan pendekatan teori perilaku. Motivasi ketiga dalam penelitian ini, peneliti ingin memperluas sampel dan menguji kepatuhan wajib pajak di Provinsi DKI Jakarta dengan tingkat kepatuhan wajib pajak yang tinggi. Berbeda dengan penelitian sebelumnya yang menambahkan variabel laten lainnya, dalam penelitian ini peneliti tidak menambah variabel laten dalam model penelitian akan tetapi peneliti akan memperkuat model penelitian dengan dengan menggunakan indikator dari peneliti sebelumnya yang telah dilakukan oleh : (Mustikasari, 2007) dan (Widi dan Bambang, 2012) yang memiliki nilai validitas dan reabilitas yang baik sehingga dapat mencerminkan kondisi populasi di lapangan yang akan akan diujikan kepada responden dengan sebaran data secara proporsional di setiap wilayah Kantor Pelayanan Pajak (KPP) di Provinsi DKI Jakarta dengan harapan dapat mengeneralisasi populasi dalam interpretasi hasil penelitian ini serta dengan akurat dalam menginterpretasikan kepatuhan pajak di DKI Jakarta.

Variabel yang digunakan dalam penelitian ini terfokus pada variabel yang terdapat pada model penelitian yang sudah dibuat oleh (Ajzen, 1991) dalam Teori Perilaku Terencana (Theory of Planned Behavior) tanpa adanya penambahan variabel lainnya.

\section{Rumusan Masalah}

1. Apakah sikap berpengaruh positif terhadap niat wajib pajak untuk berperilaku patuh terhadap pajak?

2. Apakah norma subjektif berpengaruh positif terhadap niat wajib pajak untuk berperilaku patuh terhadap pajak?

3. Apakah kontrol perilaku yang dipersepsikan berpengaruh positif terhadap niat wajib pajak untuk berperilaku patuh terhadap pajak?

4. Apakah kontrol perilaku yang dipersepsikan berpengaruh positif terhadap perilaku kepatuhan pajak secara langsung?

5. Apakah niat wajib pajak untuk berperilaku patuh berpengaruh positif terhadap perilaku kepatuhan pajak? 


\section{Landasan Teori}

Teori perilaku terencana (Theory of Planned Behavior) merupakan teori yang didasarkan pada asumsi bahwa manusia merupakan makhluk rasional yang menggunakan informasi yang memungkin bagi dirinya secara sistematis. Sebelum melakukan suatu tindakan, individu akan memikirkan implikasi atau maksud dari tindakannya sebelum memutuskan untuk melakukan perilaku tersebut atau tidak (Ajzen, 1991:184). Niat merupakan fungsi dari ketiga determinan dasar yaitu: mencerminkan sikap pribadi (personal nature), sifat sosial (social in nature), dan berhubungan dengan masalah kontrol (issues of control) (Ajzen, 2005: 117).

\section{Kaitan Antar Variabel}

\section{Pengaruh Sikap (Attitude) Terhadap Niat Berperilaku Patuh Terhadap Pajak}

Berdasarkan Theory of Planned Behavior (TPB) Ajzen (1991), perilaku individu dipengaruhi oleh adanya niat individu itu sendiri (behavioral intention) terhadap perilaku tertentu. Sedangkan niat untuk berperilaku dipengaruhi oleh variabel sikap (attitude). Sikap terhadap kepatuhan pajak dibentuk oleh keyakinan wajib pajak terhadap kepatuhan pajak yang meliputi segala hal yang diketahui oleh wajib pajak, diyakini dan dialami wajib pajak mengenai pelaksanaan peraturan perpajakan yang berlaku. Keyakinan wajib pajak tentang perilaku kepatuhan pajak ini akan menghasilkan sikap terhadap kepatuhan pajak yang dapat bersifat positif atau negatif, yang selanjutnya akan membentuk niat wajib pajak untuk berperilaku patuh atau tidak patuh terhadap peraturan perundang-undangan yang berlaku. Hasil penelitian Bobek dan Hatfield (2003) menyatakan bahwa sikap terhadap ketidakpatuhan pajak berpengaruh positif terhadap niat ketidakpatuhan pajak dalm penelitiannya di Florida dan Georgia, selain itu penelitian yang dilakukan oleh : Mustikasari (2007), Widi dan Agro (2010), Widi dan Bambang (2012) dan Theresia (2015) yang membuktikan hasil uji hipotesis sikap terhadap niat kepatuhan berpengaruh positif di Indonesia. Berdasarkan teori, penjelasan, dan hasil penelitian dan bukti empiris di atas, dalam penelitian ini dikembangkan hipotesis sebagai berikut :

H1 : Sikap terhadap kepatuhan pajak berpengaruh positif terhadap niat wajib pajak untuk berperilaku patuh terhadap pajak.

\section{Pengaruh Norma Subjektif (Subjective Norm) Terhadap Niat Berperilaku Patuh Terhadap Pajak}

Norma subjektif merupakan fungsi dari harapan yang dipersepsikan individu saat satu atau lebih orang di sekitarnya (misalnya, keluarga, teman, atasan, petugas pajak, konsultan dll) menyetujui perilaku tertentu dan memotivasi individu tersebut untuk mematuhi mereka (Ajzen, 1991). Sikap Wajib Pajak terhadap kepatuhan pajak dapat berbentuk positif atau negatif yang disebabkan karena sudah terbentuknya perilaku dari pengetahuan dan pengalaman wajib pajak maupun pengalaman orang lain yang akan membentuk niat wajib pajak untuk patuh atau tidak patuh. Namun, niat ini bisa berubah karena pengaruh orang sekitar atau faktor lainnya.

Hasil penelitian tentang kepatuhan pajak menggunakan Teori Perilaku Terencana / Theory of Planned Behavior (TPB) di New Zealand oleh Martha (2013) menunjukkan bahwa norma subjektif dalam bentuk ancaman sosial berpengaruh secara positif terhadap niat kepatuhan pajak, hasil serupa di dapatkan dalam penelitian Wahyuni (2017) di Surabaya yang menunjukan hasil penelitian bahwa norma subjektif (subjective norm) berpengaruh terhadap niat kepatuhan wajib pajak. Berdasarkan penjelasan teori diatas dan pertimbangan dan penjelasan atas penelitian terdahulu di atas, maka dalam penelitian ini dikembangkan hipotesis sebagai berikut:

$\mathrm{H} 2$ : Norma subjektif berpengaruh positif terhadap niat wajib pajak untuk berperilaku patuh terhadap pajak. 


\section{Pengaruh Kontrol Perilaku Yang Dipersepsikan (Perceived Behavioral Control) Terhadap Niat Berperilaku Patuh Terhadap Pajak}

Kontrol perilaku yang dipersepsikan / perceived behavioral control (PBC) didefinisikan sebagai persepsi seseorang / individu terhadap seberapa sanggup dalam melaksanakan suatu perilaku. Dalam kontrol perilaku ada dua aspek yang diperhatikan yaitu pertama, seberapa besar orang tersebut memiliki kontrol terhadap suatu perilaku (controllability), dan kedua, seberapa yakin orang tersebut merasa sanggup melakukan suatu perilaku (self-efficacy). PBC memiliki dua pengaruh yaitu pengaruh kepada niat berperilaku dan pengaruh langsung kepada perilaku. (Ajzen, 1991) mengatakan bahwa kontrol perilaku yang dipersepsikan mempengaruhi niat yang didasarkan atas asumsi bahwa kontrol perilaku yang dipersepsikan oleh individu akan memberikan implikasi motivasi pada orang tersebut.

Widi dan Bambang (2012) yang menyatakan temuannya bahwa sikap dan kontrol perilaku yang dipersepsikan berpengaruh kepada niat kepatuhan pajak, sejalan dengan penelitian Benk, et al (2011) yang meneliti tentang kepatuhan pajak di negara Turki dengan menggunakan pendekatan teori perilaku terencana dan mendapatkan hasil bahwa kontrol perilaku yang dipersepsikan dalam bentuk sanksi berpengaruh positif dan signifikan terhadap niat kepatuhan wajib pajak untuk patuh terhadap pajak. Berdasarkan penjabaran teori dan hubungan antara niat dengan kontrol perilaku yang dipersepsikan / perceived behavioral control (PBC) dan didukung oleh hasil penelitian terdahulu, maka dalam penelitian ini dapat dirumuskan hipotesis sebagai berikut:

H3 : Kontrol perilaku yang dipersepsikan berpengaruh positif terhadap niat wajib pajak untuk berperilaku patuh terhadap pajak

\section{Pengaruh Kontrol Perilaku Yang Dipersepsikan (Perceived Behavioral Control) Terhadap Perilaku Kepatuhan Pajak}

Pengaruh langsung kontrol perilaku yang dipersepsikan (perceived behavioral control) dapat terjadi jika terdapat actual control di luar kehendak individu sehingga memengaruhi perilaku. Semakin positif sikap terhadap perilaku dan semakin positif juga norma subjektif terhadap perilaku, maka semakin besar pengaruh kontrol yang dipersepsikan seseorang, sehingga semakin kuat niat seseorang untuk memunculkan perilaku tertentu. Akhirnya, sesuai dengan kondisi pengendalian yang nyata di lapangan (actual behavioral control) dan niat (intention) tersebut akan diwujudkan jika kesempatan itu muncul. Sebaliknya, perilaku yang dimunculkan bisa jadi bertentangan dengan niat (intention) individu tersebut. Kontrol perilaku yang dipersepsikan (perceived behavioral control) yang telah berubah akan mempengaruhi perilaku yang ditampilkan sehingga tidak sama lagi dengan yang diniatkan.

Penelitian yang dilakukan Widi dan Bambang (2012) menunjukan perilaku yang dipersepsikan berpengaruh secara langsung terhadap kepatuhan pajak, yang sejalan dengan penelitian yang dilakukan Martha (2013) yang membuktikan bahwa kontrol perilaku yang dipersepsikan (perceived behavioral control) berpengaruh positif dan signifikan terhadap perilaku ketidakpatuhan pajak di New Zealand. Berdasarkan penjelasan teori perilaku terencana tersebut dan pertimbangan di atas, maka dalam penelitian ini dapat dirumuskan hipotesis sebagai berikut:

H4 : Kontrol perilaku yang dipersepsikan berpengaruh positif secara langsung terhadap perilaku kepatuhan pajak.

\section{Pengaruh Niat Berperilaku (Behavioral Intention) Terhadap Perilaku Kepatuhan Pajak}

Dalam model Teori Perilaku Terencana (Ajzen 1991), niat berperilaku (behavioral intention) merupakan variabel antara dalam berperilaku yang artinya, perilaku individu pada dasarnya didasari oleh adanya niat untuk berperilaku. perilaku yang ditampilkan oleh individu timbul karena adanya niat atau intensi untuk berperilaku (behavioral intention). Sementara itu, munculnya niat berperilaku (behavioral intention) selain ditentukan oleh sikap (attitute) dan 
norma subjektif (subjective norm), juga ditentukan oleh kontrol perilaku yang dipersepsikan. Ketiga komponen ini berinteraksi dan menjadi indikator terhadap niat yang kemudian menentukan apakah suatu perilaku tertentu akan dilakukan atau tidak. Jadi, niat (intention) dalam penelitian ini merupakan variabel mediasi atau variabel intervening, yaitu variabel yang memengaruhi hubungan antara variabel independen (eksogenus) dengan variabel dependen (endogenus) menjadi hubungan yang tidak langsung (Ghozali, 2012: 245).

Hasil serupa pengujian atas perilaku yang didapatkan oleh Widi dan Bambang (2012) yang menyatakan bahwa niat berpengaruh positif dan signifikan terhadap kepatuhan pajak, hasil serupa sejalan dengan Handoyo (2014), Yasa dan Prayudi (2017) yang menyatakan bahwa niat berpengaruh secara positif dan signifikan terhadap kepatuhan terhadap pajak. Berdasarkan teori, penjelasan, dan kajian empiris di atas maka dapat dirumuskan hipotesis dalam penelitian ini yaitu :

H5 : Niat untuk berperilaku patuh berpengaruh positif terhadap perilaku kepatuhan pajak.

\section{METODE PENELITIAN \\ Desain Penelitian}

Penelitian ini merupakan penelitian eksplanatori (explanatory research), berdasarkan karakteristik latar belakang masalah, judul, dan tujuan penelitian maka penelitian ini merupakan penelitian yang bersifat kuantitatif yang menggunakan data primer sebagai sumber datanya. Desain penelitian ini dirancang untuk menunjukan dan menguji secara cermat dan teliti terhadap suatu objek penelitian, yaitu menguji pengaruh sikap, norma subjektif, kontrol perilaku yang dipersepsikan terhadap niat untuk berperilaku patuh terhadap pajak. Teknik analisis data penelitian ini menggunakan pendekatan Partial Least Square - Structural Equation Modeling (PLS-SEM).

\section{Populasi Dan Teknik Pemilihan Sampel}

Populasi dalam penelitian ini adalah wajib pajak orang pribadi dengan status efektif yang terdaftar atau memiliki Nomor Pokok Wajib Pajak (NPWP) di Kantor Pelayanan Pajak (KPP) di Provinsi DKI Jakarta dan melaporkan Surat Pemberitahuan Tahunan (SPT) pajak. Adapun nama, lokasi dan wilayah kerja Kantor Pelayanan Pajak (KPP) Direkrorat Jendral Pajak di Provinsi DKI Jakarta terbagi menjadi lima daerah wilayah kerja dengan jumlah kantor pelayanan pajak (KPP) yang tersebar di seluruh provinsi DKI Jakarta sebanyak 52 kantor pelayanan pajak (KPP), adapun data kantor pelayanan pajak (KPP) berdasarkan peraturan menteri keuangan nomor 62/PMK.01/2009.

Penentuan responden/pengambilan sampel dilakukan dengan menggunakan sampel berbasis non-probability sampling berupa teknik incindental sampling dan snowball sampling dengan didukung oleh teknik purposive sampling. Kisaran besarnya sampel adalah 10 kali dari besarnya indikator terbanyak yang digunakan untuk mengukur 1 variabel laten atau 10 kali dari jumlah jalur struktural terbanyak yang ditunjukan ke variabel laten tertentu dalam model struktural (Jonathan, 2015:13). Penelitian ini menggunakan 17 indikator, sehingga sampel yang dapat digunakan adalah sebesar 170 sampel, sampel sebesar 170 dapat digunakan untuk mendapatkan maximum likelihood.

Instrumen penelitian yang digunakan dalam penelitian ini adalah kuesioner, adapun instrumen penelitian dilakukan pretest pada tanggal 28-29 Mei 2018 (2 Hari). Hasil kuesioner yang sudah valid dan reliabel kemudian dilakukan penyebaran ulang untuk keperluan analisa statistik dalam penelitian ini, kuesioner disebarkan pada tanggal 28 Mei - 05 Juli 2018 (39 Hari). 


\section{Instrumen Penelitian}

Instrumen penelitian yang digunakan dalam penelitian ini adalah kuesioner, kuesioner berisi pertanyaan dan pernyataan mengenai persepsi atau opini responden tentang perilaku wajib pajak orang pribadi terhadap kepatuhan pajak yang didasari oleh niat untuk melakukannya yang tercermin dari sikap, norma subjektif dan kontrol perilaku yang dipersepsikan terhadap perilaku kepatuhan wajib pajak orang pribadi yang diambil dari konstruk model teori perilaku terencana / theory of planned behavior - Ajzen (1991) yang dikembangkan oleh (Mustikasari, 2007; serta, Widi dan Bambang, 2012).

\section{Definisi Operasional Dan Pengukuran Variabel}

Penelitian ini mempunyai dua jenis variabel, yaitu varibel eksogen dan variabel endogen. Variabel eksogen meliputi sikap terhadap perilaku kepatuhan pajak, norma subjektif, dan kontrol perilaku yang dipersepsikan, sedangkan variabel endogen meliputi niat dan perilaku kepatuhan wajib pajak.

\section{HASIL DAN PEMBAHASAN}

\section{Hasil Uji Statistik - Evaluasi Model Pengukuran (Outer Model)}

\section{Uji Reliabilitas Indikator}

Untuk setiap indikator dalam penelitian ini menunjukan nilai loading factor pada model pengukuran/outer loading menunjukan nilai yang lebih besar dari 0,7 yang artinya reabilitas tiap butir indikator telah memenuhi kriteria reabilitas.

\section{Uji Validitas Indikator}

Untuk setiap indikator dalam penelitian ini menunjukan bahwa korelasi antar variabel laten dengan indikatornya memiliki nilai loading factor yang lebih besar dibandingkan dengan korelasi antara indikator dengan variabel laten lainnya. Sehingga setiap variabel laten dalam penelitian ini sudah memilki discriminat validity yang baik dan juga menunjukan bahwa validitas setiap butir indikator sudah valid.

\section{Evaluasi Kelayakan Model}

Pada model struktural kelayakan model ditunjukkan dari besar $\mathrm{R}^{2}$ model, composite reliability, dan average variance extracted (AVE). Indikator kelayakan model dijelaskan pada Tabel 2 berikut :

Tabel 1 Kelayakan Model

\begin{tabular}{|l|rr|r|}
\hline & R Square & $\begin{array}{c}\text { Composite } \\
\text { Reliability }\end{array}$ & \multicolumn{2}{c|}{$\begin{array}{c}\text { Average Variance } \\
\text { Extracted (AVE) }\end{array}$} \\
\hline $\begin{array}{l}\text { Kontrol Perilaku Yang } \\
\text { Dipersepsikan }\end{array}$ & & 0.917 & 0.734 \\
\hline Norma Subjektif & & 0.923 & 0.750 \\
\hline Sikap & & 0.947 & 0.816 \\
\hline Kepatuhan & 0.320 & 0.978 & 0.936 \\
\hline Niat & 0.372 & 0.975 & 0.952 \\
\hline
\end{tabular}

Berdasarkan tabel 1 diatas, menunjukkan semua konstruk variabel laten memenuhi kriteria validitas, ditunjukan dari nilai Average Variance Extracted (AVE) yang lebih dari 0,50. Dan semua konstruk variabel laten dalam penelitian ini telah memenuhi kriteria reliabel, yang dapat dilihat dari nilai Composite Reability yang diatas nilai standar 0,70 yang telah ditentukan, dan 
juga nilai Cronbach's Alpha untuk semua variabel laten dalam penelitian ini menunjukkan angka yang lebih besar dari 0,6 . Nilai $\mathrm{R}$ square variabel perilaku kepatuhan wajib pajak orang pribadi sebesar 32\% dan kontrol perilaku yang dipersepsikan sebesar 37,2\% sedangkan sisanya dipengaruhi oleh variabel lain yang tidak diteliti dalam penelitian ini.

\section{Evaluasi Model Struktural (Inner Model)}

Berikut ini adalah uraian hasil uji terhadap 5 buah hipotesis pada model struktural yang diajukan pada penelitian ini :

\section{Tabel 2 Hasil Uji Pengaruh Tidak Langsung dan Total Efek}

\begin{tabular}{|l|l|l|l|l|l|}
\hline Kelayakan Model & $\begin{array}{l}\text { Kelayakan } \\
\text { Model }\end{array}$ & $\begin{array}{l}\text { Kelayakan } \\
\text { Model }\end{array}$ & $\begin{array}{l}\text { Kelayakan } \\
\text { Model }\end{array}$ & $\begin{array}{l}\text { Kelayakan } \\
\text { Model }\end{array}$ & $\begin{array}{l}\text { Kelayakan } \\
\text { Model }\end{array}$ \\
\hline Kelayakan Model & $\begin{array}{l}\text { Kelayakan } \\
\text { Model }\end{array}$ & $\begin{array}{l}\text { Kelayakan } \\
\text { Model }\end{array}$ & $\begin{array}{l}\text { Kelayakan } \\
\text { Model }\end{array}$ & $\begin{array}{l}\text { Kelayakan } \\
\text { Model }\end{array}$ & $\begin{array}{l}\text { Kelayakan } \\
\text { Model }\end{array}$ \\
\hline Kelayakan Model & $\begin{array}{l}\text { Kelayakan } \\
\text { Model }\end{array}$ & $\begin{array}{l}\text { Kelayakan } \\
\text { Model }\end{array}$ & $\begin{array}{l}\text { Kelayakan } \\
\text { Model }\end{array}$ & $\begin{array}{l}\text { Kelayakan } \\
\text { Model }\end{array}$ & $\begin{array}{l}\text { Kelayakan } \\
\text { Model }\end{array}$ \\
\hline Kelayakan Model & $\begin{array}{l}\text { Kelayakan } \\
\text { Model }\end{array}$ & $\begin{array}{l}\text { Kelayakan } \\
\text { Model }\end{array}$ & $\begin{array}{l}\text { Kelayakan } \\
\text { Model }\end{array}$ & $\begin{array}{l}\text { Kelayakan } \\
\text { Model }\end{array}$ & $\begin{array}{l}\text { Kelayakan } \\
\text { Model }\end{array}$ \\
\hline Kelayakan Model & $\begin{array}{l}\text { Kelayakan } \\
\text { Model }\end{array}$ & $\begin{array}{l}\text { Kelayakan } \\
\text { Model }\end{array}$ & $\begin{array}{l}\text { Kelayakan } \\
\text { Model }\end{array}$ & $\begin{array}{l}\text { Kelayakan } \\
\text { Model }\end{array}$ & $\begin{array}{l}\text { Kelayakan } \\
\text { Model }\end{array}$ \\
\hline Kelayakan Model & $\begin{array}{l}\text { Kelayakan } \\
\text { Model }\end{array}$ & $\begin{array}{l}\text { Kelayakan } \\
\text { Model }\end{array}$ & $\begin{array}{l}\text { Kelayakan } \\
\text { Model }\end{array}$ & $\begin{array}{l}\text { Kelayakan } \\
\text { Model }\end{array}$ & $\begin{array}{l}\text { Kelayakan } \\
\text { Model }\end{array}$ \\
\hline Kelayakan Model & $\begin{array}{l}\text { Kelayakan } \\
\text { Model }\end{array}$ & $\begin{array}{l}\text { Kelayakan } \\
\text { Model }\end{array}$ & $\begin{array}{l}\text { Kelayakan } \\
\text { Model }\end{array}$ & $\begin{array}{l}\text { Kelayakan } \\
\text { Model }\end{array}$ & $\begin{array}{l}\text { Kelayakan } \\
\text { Model }\end{array}$ \\
\hline Kelayakan Model & $\begin{array}{l}\text { Kelayakan } \\
\text { Model }\end{array}$ & $\begin{array}{l}\text { Kelayakan } \\
\text { Model }\end{array}$ & $\begin{array}{l}\text { Kelayakan } \\
\text { Model }\end{array}$ & $\begin{array}{l}\text { Kelayakan } \\
\text { Model }\end{array}$ & $\begin{array}{l}\text { Kelayakan } \\
\text { Model }\end{array}$ \\
\hline Kelayakan Model & $\begin{array}{l}\text { Kelayakan } \\
\text { Model }\end{array}$ & $\begin{array}{l}\text { Kelayakan } \\
\text { Model }\end{array}$ & $\begin{array}{l}\text { Kelayakan } \\
\text { Model }\end{array}$ & $\begin{array}{l}\text { Kelayakan } \\
\text { Model }\end{array}$ & $\begin{array}{l}\text { Kelayakan } \\
\text { Model }\end{array}$ \\
\hline Kelayakan Model & $\begin{array}{l}\text { Kelayakan } \\
\text { Model }\end{array}$ & $\begin{array}{l}\text { Kelayakan } \\
\text { Model }\end{array}$ & $\begin{array}{l}\text { Kelayakan } \\
\text { Model }\end{array}$ & $\begin{array}{l}\text { Kelayakan } \\
\text { Model }\end{array}$ & $\begin{array}{l}\text { Kelayakan } \\
\text { Model }\end{array}$ \\
\hline Kelayakan Model & $\begin{array}{l}\text { Kelayakan } \\
\text { Model }\end{array}$ & $\begin{array}{l}\text { Kelayakan } \\
\text { Model }\end{array}$ & $\begin{array}{l}\text { Kelayakan } \\
\text { Model }\end{array}$ & $\begin{array}{l}\text { Kelayakan } \\
\text { Model }\end{array}$ & $\begin{array}{l}\text { Kelayakan } \\
\text { Model }\end{array}$ \\
\hline
\end{tabular}

Tabel 2 di atas menerangkan bahwa dari 10 jalur yang ada dalam inner model terdapat 5 jalur yang secara hasil uji statistik adalah signifikan, yaitu sikap ke niat berperilaku patuh (koefisien $=$ 0,479 dan $\mathrm{t}=6.350$ ), sikap ke perilaku kepatuhan (koefisien $=0,444$ dan $\mathrm{t}=4.666$ ), sikap melalui niat ke perilaku kepatuhan (koefisien $=0,142$ dan $t=2.429$ ), kontrol perilaku yang dipersepsikan ke niat berperilaku patuh (koefisien $=0,174$ dan $\mathrm{t}=2.072$ ),

dan niat ke perilaku kepatuhan (koefisien $=0,296$ dan $\mathrm{t}=2.684$ ).

\section{Pengujian Hipotesis dan Pembahasan}

Secara ringkas, hasil pengujian dapat dilihat pada Tabel 3 berikut ini:

Tabel 3 Hasil Pengujian Hipotesis

\begin{tabular}{|l|r|r|r|r|r|}
\hline & Koefisien $(\mathbf{O})$ & T Statistics & \multicolumn{1}{|c|}{ P Values } & \multicolumn{1}{c|}{ T Table } & \multicolumn{1}{c|}{ Hipotesis } \\
\hline $\begin{array}{l}\text { Kontrol Perilaku Yang } \\
\text { Dipersepsikan -> Kepatuhan }\end{array}$ & 0.077 & 0.911 & 0.363 & 1.97 & H4 Ditolak \\
\hline $\begin{array}{l}\text { Kontrol Perilaku Yang } \\
\text { Dipersepsikan -> Niat }\end{array}$ & 0.175 & $\mathbf{2 . 1 5 6}$ & 0.032 & $\mathbf{1 . 9 7}$ & H3 Diterima \\
\hline Niat -> Kepatuhan & 0.532 & $\mathbf{6 . 9 6 9}$ & 0.000 & $\mathbf{1 . 9 7}$ & H5 Diterima \\
\hline Norma Subjektif -> Niat & 0.078 & 1.038 & 0.300 & 1.97 & H2 Ditolak \\
\hline Sikap -> Niat & 0.480 & $\mathbf{6 . 7 9 5}$ & 0.000 & $\mathbf{1 . 9 7}$ & H1 Diterima \\
\hline
\end{tabular}




\section{Diskusi}

\section{Sikap Terhadap Kepatuhan Pajak Berpengaruh Positif Terhadap Niat Wajib Pajak Untuk Berperilaku Patuh Terhadap Pajak.}

Dalam pengujian hipotesis kesatu diterima karena berpengaruh positif dan signifikan. Artinya sikap berpengaruh positif dan signifikan terhadap niat berperilaku patuh kepada pajak pada wajib pajak di Provinsi DKI Jakarta. Temuan empiris tersebut didukung oleh fenomena yang ada di Provinsi DKI Jakarta, dimana DKI Jakarta merupakah daerah dengan tingkat kepatuhan pajak yang baik.Temuan empiris ini juga didukung oleh teori yang melandasi penelitian ini yaitu Theory Of Planned Behavior (TPB) yang menyatakan bahwa sikap yang positif timbul karena adanya evaluasi atas hasil dari perilaku yang dilakukannya memberikan efek yang positif pula. Selain itu penelitian ini juga didukung oleh peneliti terdahulu seperti Bobek dan Hatfield (2003), Widi dan Bambang (2012), Wahyuni, Sulindawati dan Yasa (2017) yang menyatakan bahwa sikap menjunjukan arah yang positif dan signifikan terhadap niat wajib pajak orang pribadi dalam berperilaku patuh.

\section{Norma Subjektif Berpengaruh Positif Terhadap Niat Wajib Pajak Untuk Berperilaku Patuh Terhadap Pajak.}

Dalam pengujian hipotesis kedua ditolak karena berpengaruh positif namun tidak signifikan. Artinya norma subjektif berpengaruh positif namun tidak signifikan terhadap niat berperilaku patuh kepada pajak pada wajib pajak di Provinsi DKI Jakarta. Temuan empiris ini didukung oleh teori yang melandasi penelitian ini yaitu Theory Of Planned Behavior (TPB) yang menyatakan bahwa seorang individu akan cenderung melakukan perilaku jika termotivasi oleh orang lain yang menyetujuinya untuk melakukan perilaku tersebut, seseorang bisa terpengaruh atau tidak terpengaruh oleh keadaan sosial (Ajzen, 1991). Pengaruh lingkungan dan orang-orang disekitarnya berpangaruh positif menambah motivasi wajib pajak di Provinsi DKI Jakarta dalam berniat melakukan kepatuhan. Namun hanya sedikit pengaruhnya sehingga tidak membuat wajib pajak berniat untuk melakukan perilaku kepatuhan pajaknya. Selain itu penelitian ini juga didukung oleh peneliti terdahulu yaitu Trivedi dan Shehata (2005), Widi dan Agro (2010), Ernawati dan Purnomosidhi (2010), Tarmidi dan Waluyo (2014) yang mengungkapkan bahwa norma subjektif tidak signifikan berpengaruh terhadap niat untuk berperilaku patuh.

\section{Kontrol Perilaku Yang Dipersepsikan Berpengaruh Positif Terhadap Niat Wajib Pajak Untuk Berperilaku Patuh Terhadap Pajak.}

Dalam pengujian ketiga diterima karena berpengaruh positif dan signifikan. Artinya kontrol perilaku yang dipersepsikan berpengaruh positif dan signifikan terhadap niat berperilaku patuh kepada pajak pada wajib pajak di Provinsi DKI Jakarta. Temuan empiris tersebut didukung oleh fakta yang ada di Provinsi DKI Jakarta, dimana DKI Jakarta merupakah daerah dengan tingkat kepatuhan pajak yang baik yang mencerminkan kontrol perilaku wajib pajak yang baik. Temuan empiris ini juga didukung oleh teori yang melandasi penelitian ini yaitu Theory Of Planned Behavior (TPB) yang menyatakan bahwa kontrol perilaku yang dipersepsikan timbul karena adanya keyakinan kontrol (control beliefs) yang kemudian melahirkan kontrol perilaku yang dipersepsikan, yang merupakan keyakinan wajib pajak tentang keberadaan hal-hal yang mendukung atau menghambat perilaku yang akan dilakukan. Selain itu penelitian ini juga didukung oleh peneliti terdahulu seperti Martha (2012), Bobek dan Hatfield (2003), Mutikasari (2007), Oktaviani (2014), Depari (2014), Putri (2107), Yasa dan Prayudi (2017) yang menyatakan bahwa kontrol perilaku yang dipersepsikan berpengaruh positif dan signifikan terhadap niat dan kepatuhan pajak. 


\section{Kontrol Perilaku Yang Dipersepsikan Berpengaruh Positif Secara Langsung Terhadap Perilaku Kepatuhan Pajak.}

Dalam pengujian hipotesis keempat ditolak karena berpengaruh positif dan tidak signifikan. Artinya kontrol perilaku yang dipersepsikan berpengaruh positif dan tidak signifikan terhadap perilaku patuh kepada pajak secara langsung pada wajib pajak di Provinsi DKI Jakarta. Temuan empiris tersebut didukung oleh fakta hasil temuan empiris pada pengujian hipotesis ke-3 (ketiga) yang menunjukkan koefisien kontrol perilaku yang ada di Provinsi DKI Jakarta yaitu sebesar $17,5 \%$ yang artinya kontrol perilaku yang dipersepsikan yang disebabkan karena adanya sistem dan regulasi, tidak besar pengaruhnya dalam menambah niat berperilaku patuh, oleh sebab itu wajib pajak tidak dapat melakukan perilaku kepatuhan pajak secara langsung tanpa didasari oleh niat yang kuat. Hasil ini juga didukung oleh penelitian yang dilakukan oleh Bobek dan Hatfield (2003), Trivedi dan Shehata (2005), Harinurdin (2009), Tarmidi dan Waluyo (2014) dalam penelitiannya di Jakarta, Widi dan Agro (2010) yang menyatakan bahwa kontrol perilaku yang dipersepsikan berpengaruh tidak signifikan terhadap perilaku kepatuhan pajak.

\section{Niat Untuk Berperilaku Patuh Berpengaruh Positif Terhadap Perilaku Kepatuhan Pajak.}

Dalam pengujian hipotesis kelima diterima karena berpengaruh positif dan signifikan. Artinya niat berpengaruh positif dan signifikan terhadap perilaku kepatuhan pajak pada wajib pajak di Provinsi DKI Jakarta. Temuan empiris didukung oleh Theory Of Planned Behavior (TPB) yang menyatakan bahwa perilaku individu pada dasarnya didasari oleh adanya niat untuk berperilaku. Hasil penelitian ini didukung oleh semua penelitian terdahulu dalam penelitian ini yang menyatakan bahwa niat berpengaruh positif dan signifikan terhadap perilaku kepatuhan perpajakan.

\section{KESIMPULAN DAN SARAN Kesimpulan}

Secara keseluruhan berdasarkan hasil pengujian hipotesis dan temuan dalam penelitian ini dapat ditarik kesimpulan bahwa perilaku kepatuhan pajak merupakan perilaku yang didasari oleh niat wajib pajak untuk berperilaku patuh terhadap pajak. Artinya bahwa semakin tinggi/besar niat wajib pajak untuk berperilaku patuh terhadap pajak, maka akan semakin tinggi/besar pula kemungkinan orang tersebut untuk mewujudkan perilaku patuh terhadap pajak.

Dan niat wajib pajak tersebut ditentukan oleh sikap (attitute), norma subjektif (subjective norm), dan juga ditentukan oleh kontrol perilaku yang dipersepsikan/perceived behavioral control (PBC) wajib pajak orang pribadi di Provinsi DKI Jakarta). Sehingga dapat ditarik kesimpulan bahwa pernyataan dalam teori perilaku terencana/Theory of Planned Behavior (TPB) yang diutarakan oleh Ajzen (1991) dalam teorinya tersebut ternyata benar adanya dan masih sesuai dengan kondisi dan situasi saat ini dalam menggambarkan perilaku individu (wajib pajak orang pribadi di Provinsi DKI Jakarta)

\section{Saran}

1. Bagi institusi atau pemerintah khususnya Direktoriat Jendral Pajak (DJP) :

Hasil penelitian di Provinsi DKI Jakarta ini membuktikan bahwa sikap wajib, norma subjektif, kontrol perilaku wajib pajak, pajak perlu dibina agar menghasilkan niat berperilaku dan mewujudkan perilaku patuh terhadap pajak tersebut. Dan pemerintah juga harus memperbaiki sistem perpajakannya, sehingga pengawasan terhadap kepatuhan pajak akan efektif, sistem pengawasan yang efektif dan didukung oleh regulasi yang memadai akan membuat kontrol perilaku yang baik terhadap wajib pajak orang pribadi, sehingga menciptakan kontrol perilaku yang membuat wajib pajak takut untuk tidak berperilaku patuh. 
2. Bagi peneliti yang akan datang disarankan:

a. Agar penelitian yang akan datang menambahkan variabel laten lainnya seperti kewajiban moral individu, tekanan finansial dan variabel laten lainnya (Mutikasari, 2007) sehingga dapat memprediksi dengan lebih baik dan menggambarkan perilaku yang lebih baik lagi yang dalam penelitian ini dapat dilihat dari nilai $\mathrm{R} 2$ yang rendah.

b. Dan juga menggunakan skop penelitian yang lebih luas lagi dengan tingkat proporsi sebaran data yang lebih proporsional, sehingga bisa lebih akurat lagi dalam menggambarkan perilaku kepatuhan wajib pajak orang pribadi baik di suatu provinsi maupun diseluruh Indonesia.

c. Peneliti juga menyarankan peneliti berikutnya meneliti variabel-variabel lain, menerapkan teori lain, atau model lain dengan harapan menghasilkan temuan yang lebih bermanfaat bagi pemerintah, praktisi dan pengembangan teori perilaku perpajakan

\section{REFERENSI}

Aini, Aldia Oktaviani., Budiman, Judi., Wijayanti, Provita. (2014). Kepatuhan Wajib Pajak Badan Perusahaan Manufaktur Di Semarang Dalam Perspektif Tax Profesional. Jurnal InFestasi, Vol. 10 No.1 Juni 2014, Hal. 25-35.

Ajzen, I. (2005). Attitude, Personality, and Behavior. 2nd Edition. Berkshire, UK Open University Press-McGraw Hill Education.

2002. Constructing a TPB Questionnaire: Conceptual and Methodological Considerations. September (Revised January, 2006).

1991. The Theory Planned Behavior. Organizational Behavior and Human Deci-sion Processes. 50: 179-211.

Bobek, D. dan Richard C. Hatfield. (2003). An Investigation of Theory of Planned Behavior and the Role of Moral Obligation in Tax Compliance. Behavioral Research in Accounting. 15: $13-38$.

Bobek, D., Richard C. Hatfield, dan Kristin Wentzel. (2007). An Investigation of

Why Taxpayers Prefer Refunds: A Theory of Planned Behavior Approach. The Journal of the American Taxation Association (JATA). Vol. 29, No. 1 Spring 2007 pp. 93-111

Bobek, D., Robin W., John T. (2007). The Social Norms of Tax Compliance:

Evidence from Australia, Singapore, and the United States. Journal of Business Ethics. 74:49-64. Springer 2007. DOI 10.1007/s10551-006-9219-x

Damayanti, Theresia Woro., Sutrisno., Subekti, Imam., Baridwan, Zaki. (2015). Trust and Uncertainty Orientation: An Efforts to Create Tax Compliance in Social Psychology Framework. 2nd Global Conference on Business and Social Science-2015, GCBSS-2015, 17-18 September 2015, Bali, Indonesia. Procedia - Social and Behavioral Sciences 211 ( 2015 ) $938-944$.

Depari, Ruben Alfa. (2014). Analisis Sikap, Norma Subjektif, Dan Kontrol Perilaku Oleh Wajib Pajak (Studi Kasus Di KPP Pratama Salatiga). Skripsi. Universitas Kristen Satya Wacana.

Ernawati, Widi Dwi and Purnomosidhi, Bambang. (2015). Pe.ngaruh Sikap, Norma Subjektif, Kontrol Perilaku yang Dipersepsikan, dan Sunset Policy Terhadap Kepatuhan Wajib Pajak dengan Niat Sebagai Variabel Intervening. Jurnal Akuntansi.

Fishbein, Martin., Ajzen, Icek. (1975). Belief, Attitude, Intention And Behavior : An Introduction to Theory and Reaserch. Canada : Addison-Wesley Series In Social Psychology. ISBN 0201-02089-0.

Ghozali, Imam. (2012). Aplikasi Analisis Multivariate Dengan Program IBM SPSS 2.0. Semarang: Badan Penerbit Undip. ISBN : 979.704.300.2. 
Ghozali, Imam. (2015). Aplikasi Analisis PLS Dengan Program SmartPLS. Semarang: Undip.

Handoyono, Rudi. (2014). Analisis Kepatuhan Wajib Pajak Orang Pribadi Di KPP Pratama Semarang Candisari. AKUN-t: Vol. 2 No 2 April 2014/ ISSN 23032.

Mustikasari, Elia. (2007). Kajian Empiris tentang Kepatuhan Wajib Pajak Badan di Perusahaan Industri Pengolahan di Surabaya, Seminar Nasional Akuntansi X. Makasar.

Novianti, Agnes Findia. (2017). An Investigation Of The Theory Of Planned Behaviour And The Role Of Tax Amnesty In Tax Compliance. Jurnal Akuntansi.

Pangestu, Ferdyant dan Rusmana, Oman. (2012). Analisis Faktor-Faktor Yang Berpengaruh Terhadap Tax Compliance Penyetoran Spt Masa (Survei pada PKP yang Terdaftar di KPP Pratama Purwokerto). Simposium Nasional Akuntansi XV Banjarmasin 2012.

Putri, Layli Yobapritika. (2017), Pengaruh Sikap, Norma Subjektif, Dan Kontrol Keperilakuan Yang Dipersepsikan Terhadap Kepatuhan Wajib Pajak Orang Pribadi Di Kota Yogyakarta. Jurnal Profita Edisi 3 Tahun 2017.

Sarwono, Jonathan., Narimawati, Umi. (2015). Membuat Skripsi, Tesis, dan Disertasi dengan Partial Least Square SEM (PLS-SEM). Yogyakarta: Andi Offset.

Sholihin, Mahfud., Ratmono, Dwi. (2013). Analisis SEM-PLS dengan WarpPLS 3.0 untuk Hubungan Nonlinier dalam Penelitian Sosial dan Bisnis. Yogyakarta : Andi Offset.

Smart, Martha. (2013). Applying The Theory Of Planned Behaviour And Structural Equation Modelling To Tax Compliance Behaviour: A New Zealand Study. Journal of Accountancy. University of Canterbury, New Zealand

Tarmidi, Deden., Waluyo. (2014). Faktor-Faktor Yang Mempengaruhi Kepatuhan Pajak, Dengan Pendekatan Perilaku Dan Etika (Studi Empiris Pada Perusahaan PMA Yang Terdaftar Di Kanwil DJP Jakarta Khusus). Jurnal TEKUN/Volume V, No. 01, Maret 2014: 49-68.

Trivedi, Viswanath Umashanker., Shehata, Mohamed., Mestelman, Stuart. (2005). Attitudes, Incentives, And Tax Compliance. Canada Discal Journal. Canada Customs and Revenue Agency, CCRA Annual Report to Parliament 2003-2004 (Ottawa:Canada Customs and Revenue Agency, 2004), 1-24, exhibit 6.

Wahyuni, Made., Sulindawati, Ni Luh Gede Erni., Yasa, I Nyoman Putra. (2017). Pengaruh Sikap Dan Niat Berperilaku Patuh Terhadap Kepatuhan Wajib Pajak Orang Pribadi. $e$ Journal S1 Ak Universitas Pendidikan Ganesha Jurusan Akuntansi Program S1 (Vol: 8 No: 2 Tahun 2017).

Widi, Hidayat dan Argo, Adhi. (2010). Studi Empiris Theory Planned Behaviour dan Pengaruh Kewajiban Moral pada Perilaku Ketidakpatuhan Wajib Pajak Orang Pribadi. Jurnal Akuntansi dan Keuangan. Vol 12(2). Pp 82-93.

Widi, Dwi dan Bambang, Purnomosidhi. (2012). Pengaruh Sikap, Norma Subjektif, Kontrol Perilaku yang Dipersepsikan, dan Sunset Policy Terhadap Kepatuhan Wajib Pajak dengan Niat Sebagai Variabel Intervening. Jurnal Akuntansi.

Yasa dan Prayudi. (2017). Perilaku Kepatuhan Perpajakan dalam Perspektif Teori Perilaku Terencana. Seminar Nasional Riset Inovatif 2017. ISBN: 978-602-6428-11-0. 